OPEN ACCESS

Edited by:

Eung-Soo Kim,

Inha University, South Korea

Reviewed by:

Yutaka Kawarabayasi,

Kyushu University, Japan

Sergio Adrian Guerrero,

Universidad Nacional del Litoral,

Argentina

*Correspondence:

Pil Kim

kimp@catholic.ac.kr

Specialty section:

This article was submitted to

Microbial Physiology and Metabolism,

a section of the journal

Frontiers in Microbiology

Received: 02 July 2018 Accepted: 03 October 2018 Published: 26 October 2018

Citation:

Lee MJ and Kim P (2018) Recombinant Protein Expression

System in Corynebacterium glutamicum and Its Application.

Front. Microbiol. 9:2523.

doi: 10.3389/fmicb.2018.02523

\section{Recombinant Protein Expression System in Corynebacterium glutamicum and Its Application}

\author{
Min Ju Lee and Pil Kim* \\ Department of Biotechnology, The Catholirc University of Korea, Bucheon, South Korea
}

Corynebacterium glutamicum, a soil-derived gram-positive actinobacterium, has been widely used for the production of biochemical molecules such as amino acids (i.e., L-glutamate and L-lysine), nucleic acids, alcohols, and organic acids. The metabolism of the bacterium has been engineered to increase the production of the target biochemical molecule, which requires a cytosolic enzyme expression. As recent demand for new proteinaceous biologics (such as antibodies, growth factors, and hormones) increase, C. glutamicum is attracting industrial interest as a recombinant protein expression host for therapeutic protein production due to the advantages such as low protease activity without endotoxin activity. In this review, we have summarized the recent studies on the heterologous expression of the recombinant protein in C. glutamicum for metabolic engineering, expansion of substrate availability, and recombinant protein secretion. We have also outlined the advances in genetic components such as promoters, surface anchoring systems, and secretory signal sequences in C. glutamicum for effective recombinant protein expression.

Keywords: Corynebacterium glutamicium, expression host systems, cytosolic expression, secretory expression, recombinant protein, surface displayed expression

\section{INTRODUCTION}

Recombinant proteins, including biologics and enzymes, are useful in the biopharmaceutical, food, and chemical industries (Butenas, 2013). To date, more than 400 recombinant biologics have been approved by the US Food and Drug Administration (FDA), and more recombinant biologics are in the clinical development stage (Sanchez-Garcia et al., 2016). The demand for new biologics (such as antibodies, growth factors, and hormones) for the treatment of severe chronic diseases (such as cancer, anemia, and multiple sclerosis) has increased, and the market for recombinant proteins is expected to grow over the next few decades (https:// www.grandviewresearch.com/press-release/global-protein-expression-market). Corynebacterium glutamicum, which is a non-lethal and non-emulsifying gram-positive bacterium, exhibits a low protease activity in the culture supernatant and can secrete protease-sensitive proteins into the culture supernatant (Liu et al., 2013). Absence of lipopolysaccharide (endotoxin) in C. glutamicum, which is the gram-negative bacterial surface component that should be removed for the production of therapeutic proteins (Srivastava and Deb, 2005), may increase the heterologous protein yield by minimizing the purification steps. C. glutamicum has generally been used as a generally recognized as safe (GRAS) host for the industrial production of biochemicals including L-glutamate and L-lysine (Lee et al., 2016). As a result, C. glutamicum is favorable for producing high yields of proteins that are difficult to secrete in the host and the proteins that must remain active in a non-pathogenic environment. 
The industrial production of biochemicals including nutraceuticals has been established using C. glutamicum as a host (Nakayama et al., 1961). Since C. glutamicum was first isolated as an L-glutamate producer by Kinoshita and Udaka in 1956 (Kyowa Hakko Bio Ltd. Co., Japan) (Kinoshita et al., 1957), many L-amino acids have been produced using this soil bacterium. In addition, many biochemicals (biopolymers, organic acids, rare sugars, etc.) have been commercially produced from metabolically engineered C. glutamicum strains. The metabolic processes of C. glutamicum may be rationally modified for the production of various biochemicals using three approaches: (1) amplification of biosynthetic pathway enzymes to increase target products, (2) reduction of by-product formation, and (3) introduction of important enzyme feedback controls to optimize target biomaterials. All these approaches involve the use of recombinant protein expression in the cytosol to produce beneficial biochemicals.

This review summarizes the recent studies on the heterologous expression of the recombinant protein in C. glutamicum for various applications including metabolic engineering, expansion of substrate availability, and recombinant protein secretion. It also lists the advancements of genetic components for effective recombinant protein expression.

\section{CYTOSOLIC PROTEIN EXPRESSION IN C. glutamicum FOR METABOLIC ENGINEERING}

A common method for producing biochemicals from C. glutamicum is the overexpression of enzymes involved in the biosynthetic pathway of the target product in cytosol (Table 1), which involves recombinant protein expression. Jensen and Wendisch overexpressed the ornithine cyclodeaminase (OCD) gene from Pseudomonas putida for the production of L-proline, which is a biochemical that is typically used as a commodity chemical or feed additive; this overexpression resulted in an increased product yield of $0.36 \mathrm{~g}$ proline/substrate (Jensen and Wendisch, 2013). Another foreign protein (D-lactate dehydrogenase) from Lactobacillus delbrueckii was expressed to address the limitations of using lactic acid bacteria, which require a relatively expensive complex medium for D-lactate production, and Okino et al. reported a high level of D-lactate production in C. glutamicum (Okino et al., 2008).

Jojima et al. designed protein expression systems as a way to reduce by-product formation in L-alanine production (Jojima et al., 2015). In a C. glutamicum strain, genes involved in the organic acid biosynthetic pathway $(\Delta l d h A$ : lactate dehydrogenase; $\triangle p p c$ : phosphoenolpyruvate carboxylase; $\Delta a l r$ : alanine racemase) were inactivated; however, the alaD of Lysinibacillus sphaericus (encoding L-alanine dehydrogenase) along with the gapA of $L$. sphaericus (encoding glyceraldehyde 3-phosphate dehydrogenase promoting glucose consumption) were overexpressed, leading to a metabolic flux from organic acids to L-alanine. As a result, a high product (L-alanine) concentration (98 g/L $\mathrm{L}_{\text {medium }}$ ) was obtained.
As a large amount of oxygen and energy is required in the production of L-amino acids in C. glutamicum (Kwong and Rao, 1991), Liu et al. reported a novel approach for improving the intracellular oxygen supply by expressing hemoglobin (Liu et al., 2008). They modulated the metabolism to increase the productivity of L-glutamate by inducing metabolic flux into the tricarboxylic acid (TCA) cycle and additionally expressed the hemoglobin protein of Vitreoscilla sp. (VHb) in C. glutamicum to increase the oxygen and energy supply, resulting in the increased production of L-glutamine.

In addition, cytosolic protein expression in C. glutamicum has contributed to the production of biochemicals such as polyhydroxyalkanoate (PHA) (Matsumoto et al., 2011), ethanol (Jojima et al., 2015), and $\gamma$-aminobutyric acid (GABA) (Choi et al., 2015). The industrial techniques for the production of rare saccharides such as D-tagatose (Shin et al., 2016), D-sorbose and D-psicose (Yang et al., 2015), D-allose (https://patents.google. com/patent/WO2017111339A1/en), and GDP-L-fucose (Chin et al., 2013) are also the methods of nutraceutical production that involve cytosolic protein overexpression in C. glutamicum.

\section{SURFACE-DISPLAYED ENZYME EXPRESSION IN C. glutamicum Present Applications of Surface-Displayed Systems}

The cell surface display systems can be used for a wide range of biotechnological and industrial applications: (1) a live vaccine that induces antigen-specific antibody responses by exposing heterologous epitopes to pathogenic bacterial cells (Lee et al., 2000); (2) screening of displayed peptides by sequential binding and elution (Boder and Wittrup, 1997); (3) expression of surface antigens to produce polyclonal antibodies in animals (Martineau et al., 1991); (4) using biological adsorbents for the removal of heavy metals (Bae et al., 2000); (5) using biological adsorbents for the removal of herbicides and environmental pollutants (Dhillon et al., 1999); (6) detecting single amino acid changes in target peptides after random mutagenesis; and (7) using biosensors with immobilized enzymes, receptors, or other signal-sensitive components (Aoki et al., 2002).

Purified enzymes have been used in many industrial bioconversion processes as immobilized enzyme catalysts. The immobilization of enzymes is time-consuming and costly because it involves several steps: growth of culture, disruption of cells, purification of enzymes, and immobilization of enzymes. When an enzyme is expressed on the cell surface of a microorganism as a whole-cell catalyst, additional purification steps are unnecessary and the whole-cell catalyst can be used repeatedly.

\section{Development of Surface-Display Systems}

The first surface expression system was developed in the mid1980s to attach small peptides to proteins fused to bacteriophage surfaces (Smith, 1985). Thereafter, various phage display systems have been developed to express heterologous proteins on the surface of phages; however, the size of exogenous proteins that 
TABLE 1 | Examples of cytosolic protein expressions in Corynebacterium g/utamicum for productions of biochemicals.

\begin{tabular}{|c|c|c|c|c|c|c|c|c|}
\hline Recombinant Protein & Product & Applications & Source & Producer & $\begin{array}{l}\text { Titer } \\
\left.\text { (g/ } / L_{\text {medium }}\right)\end{array}$ & $\begin{array}{l}\text { Productivity } \\
(\mathrm{g} / \mathrm{L} / \mathrm{h})\end{array}$ & $\begin{array}{c}\text { Yield } \\
\text { (g groduct/ } \\
\text { gsubstrate) }\end{array}$ & References \\
\hline \multicolumn{9}{|c|}{ A. L-AMINO ACIDS AND RELATED BIOCHEMICALS } \\
\hline $\begin{array}{l}\text { Alanine dehydrogenase } \\
\text { (AlaD) }\end{array}$ & L-Alanine & Supplement in animal feed & $\begin{array}{l}\text { Lysinibacillus } \\
\text { sphaericus }\end{array}$ & $\begin{array}{l}\text { R } \\
\Delta / d h A \Delta p p c \\
\Delta a l r+\text { AlaD }+ \\
\text { GapA }\end{array}$ & 98 & 3.1 & 0.83 & $\begin{array}{l}\text { Jojima et al., } \\
2010\end{array}$ \\
\hline $\begin{array}{l}\text { Glyceraldehyde } \\
\text { 3-phosphate } \\
\text { dehydrogenase (GapA) }\end{array}$ & & & $\begin{array}{l}\text { Corynebacterium } \\
\text { glutamicum }\end{array}$ & & & & & \\
\hline $\begin{array}{l}\text { Ornithine } \\
\text { acetyltransferase (ArgJ) }\end{array}$ & L-Citrulline & $\begin{array}{l}\text { Intermediate in the arginine } \\
\text { biosynthesis, health, and } \\
\text { nutrition applications }\end{array}$ & $\begin{array}{l}\text { Corynebacterium } \\
\text { glutamicum }\end{array}$ & $\begin{array}{l}\text { ATCC } 13032 \\
\Delta \text { argG } \triangle \arg R+ \\
\text { ArgJ }\end{array}$ & 8.5 & 0.1 & 0.11 & $\begin{array}{l}\text { Zhang et al., } \\
2018\end{array}$ \\
\hline Hemoglobin (Vgb) & L-Glutamine & Flavor enhancer & Vitreoscilla & $\begin{array}{l}\text { ATCC14067 } \\
+ \text { GlnA (Y405F) } \\
+ \text { Vgb }\end{array}$ & 17.3 & 0.36 & 0.08 & Liu et al., 2008 \\
\hline $\begin{array}{l}\text { 3-deoxy-D-arabino- } \\
\text { heptulosonate } \\
\text { 7-phosphate synthase } \\
\text { (DS), } \\
\text { Chorismate mutase (CM), } \\
\text { Prephenate dehydratase } \\
\text { (PD) }\end{array}$ & L-Phenylalanine & Aromatic amino acids & $\begin{array}{l}\text { Corynebacterium } \\
\text { glutamicum }\end{array}$ & $\begin{array}{l}\mathrm{KY} 10865 \\
+\mathrm{DS}+\mathrm{CM}+ \\
\mathrm{PD}\end{array}$ & 28 & 0.35 & 0.47 & $\begin{array}{l}\text { Ikeda and } \\
\text { Katsumata, } \\
1992\end{array}$ \\
\hline $\begin{array}{l}\text { Oornithine } \\
\text { cyclodeaminase (ArgB) }\end{array}$ & L-Proline & $\begin{array}{l}\text { Pharmaceutical and osmotic } \\
\text { applications and feed additive }\end{array}$ & $\begin{array}{l}\text { Pseudomonas } \\
\text { putida }\end{array}$ & $\begin{array}{l}\text { ATCC13032 } \\
\triangle \operatorname{argR} \triangle \arg F+ \\
\text { ArgB (A49V, } \\
\text { M54V) }\end{array}$ & 12.7 & 0.52 & 0.36 & $\begin{array}{l}\text { Jensen and } \\
\text { Wendisch, } \\
2013\end{array}$ \\
\hline Transketolase (TK) & L-Tryptophan & Supplement in animal feed & $\begin{array}{l}\text { Corynebacterium } \\
\text { glutamicum }\end{array}$ & $\begin{array}{l}\text { KY9218 } \\
+ \text { DS + PGD + } \\
\text { TK }\end{array}$ & 58 & 0.73 & 0.25 & $\begin{array}{l}\text { Ikeda and } \\
\text { Katsumata, } \\
1999\end{array}$ \\
\hline $\begin{array}{l}\text { 3-eoxy-D-arabino- } \\
\text { heptulosonate } \\
\text { 7-phosphate synthase } \\
\text { (DS), } \\
\text { Chorismate mutase (CM) }\end{array}$ & L-Tyrosine & - & $\begin{array}{l}\text { Corynebacterium } \\
\text { glutamicum }\end{array}$ & $\begin{array}{l}\text { KY10865 } \\
+\mathrm{DS}+\mathrm{CM}\end{array}$ & 26 & 0.32 & 0.43 & $\begin{array}{l}\text { Ikeda and } \\
\text { Katsumata, } \\
1992\end{array}$ \\
\hline \multicolumn{9}{|l|}{ B. ORGANIC ACIDS } \\
\hline $\begin{array}{l}\text { D-lactate dehydrogenase } \\
\text { (D-LDH) }\end{array}$ & D-Lactate & Food packaging & $\begin{array}{l}\text { Lactobacillus } \\
\text { delbrueckii }\end{array}$ & $\begin{array}{l}\mathrm{R} \\
\Delta / d h A+\mathrm{D}-\mathrm{LDH}\end{array}$ & 120 & 4 & 0.8 & $\begin{array}{l}\text { Okino et al., } \\
2008\end{array}$ \\
\hline $\begin{array}{l}\text { Glyoxylate reductase } \\
\text { (YcdW) }\end{array}$ & Glycolate & $\begin{array}{l}\text { Cosmetic industry to improve } \\
\text { skin texture and to treat skin } \\
\text { diseases }\end{array}$ & Escherichia coli & $\begin{array}{l}\text { ATCC13032 } \\
\text { } \text { aceB icdGTG } \\
+ \text { YcdW }\end{array}$ & 5.3 & 0.1 & 0.18 & $\begin{array}{l}\text { Zahoor et al., } \\
2014\end{array}$ \\
\hline $\begin{array}{l}\text { Cis-aconitate } \\
\text { decarboxylase (CAD1) }\end{array}$ & Itaconic acid & $\begin{array}{l}\text { Synthesis of resins, lattices, } \\
\text { fibers, detergents, cleaners, } \\
\text { and bioactive compounds }\end{array}$ & Aspergillus terreus & $\begin{array}{l}\text { ATCC13032 } \\
\text { icd A1G + MalE } \\
+ \text { CAD1 } \\
\text { (optimized) }\end{array}$ & 7.8 & 0.27 & 0.03 & $\begin{array}{l}\text { Otten et al., } \\
2015\end{array}$ \\
\hline $\begin{array}{l}\text { Acetohydroxy acid } \\
\text { synthase (IlvBN), } \\
\text { Acetohydroxy acid } \\
\text { isomeroreductase (IIvC), } \\
\text { Dihydroxy acid } \\
\text { dehydratase (IIvD) }\end{array}$ & 2-Ketoisovalerate & $\begin{array}{l}\text { Precursor of L-valine, } \\
\text { L-leucine, and pantothenate } \\
\text { synthesis; substitute for } \\
\text { L-valine or L-leucine in chronic } \\
\text { kidney disease patients }\end{array}$ & $\begin{array}{l}\text { Corynebacterium } \\
\text { glutamicum }\end{array}$ & $\begin{array}{l}\text { ATCC13032 } \\
\Delta / t b R \Delta i l v E \\
\Delta p r p C 1 \Delta p r p C 2 \\
+ \text { PgltA mut_L1 } \\
+ \text { IIvBN + IVC + } \\
\text { IIvD }\end{array}$ & 35 & 0.79 & 0.15 & $\begin{array}{l}\text { Buchholz } \\
\text { et al., } 2013\end{array}$ \\
\hline $\begin{array}{l}\text { Isopropylmalate synthase } \\
\text { (leuA) }\end{array}$ & 2-Ketoisocaprate & Therapeutic agent & $\begin{array}{l}\text { Corynebacterium } \\
\text { glutamicum }\end{array}$ & $\begin{array}{l}\text { VB } \\
+ \text { IlvBN }+ \text { lilvC }+ \\
\text { IlvD + leuA } \\
\text { (G462D) }\end{array}$ & 9.2 & 0.37 & 0.24 & $\begin{array}{l}\text { Bückle-Vallant } \\
\text { et al., } 2014\end{array}$ \\
\hline $\begin{array}{l}\text { Alcohol dehydrogenase } \\
(\mathrm{ADH})\end{array}$ & 12-Ketooleic acid & $\begin{array}{l}\text { Plasticizers, lubricants, } \\
\text { detergents, cosmetics, and } \\
\text { surfactants. }\end{array}$ & Micrococcus luteus & $\begin{array}{l}\text { ATCC13032 } \\
+ \text { GFP + ADH }\end{array}$ & - & 1.2 & $74 \%$ & $\begin{array}{l}\text { Lee et al., } \\
2015\end{array}$ \\
\hline \multicolumn{9}{|l|}{ C. POLYMERS } \\
\hline $\begin{array}{l}\text { Lysine decarboxylase } \\
\text { (CadA) }\end{array}$ & Cadaverine & $\begin{array}{l}\text { Replacement for the } \\
\text { oil-derived } \\
\text { hexamethylenediamine for } \\
\text { polyamide } 66 \text { (nylon 66) }\end{array}$ & Escherichia coli & $\begin{array}{l}\text { ATCC13032 } \\
\text { shom + AmyA } \\
+ \text { CadA }\end{array}$ & $22.9 \mathrm{mM}$ & - & - & $\begin{array}{l}\text { Tateno et al., } \\
2009\end{array}$ \\
\hline
\end{tabular}


TABLE 1 | Continued

\begin{tabular}{|c|c|c|c|c|c|c|c|c|}
\hline Recombinant Protein & Product & Applications & Source & Producer & $\begin{array}{c}\text { Titer } \\
\left(g / L_{\text {medium }}\right)\end{array}$ & $\begin{array}{l}\text { Productivity } \\
(\mathrm{g} / \mathrm{L} / \mathrm{h})\end{array}$ & $\begin{array}{c}\text { Yield } \\
\text { (g groduct } / \\
\text { gsubstrate) }\end{array}$ & References \\
\hline $\begin{array}{l}\text { Glutamate decarboxylase } \\
\text { (GadB) }\end{array}$ & $\begin{array}{l}\text { Gamma- } \\
\text { aminobutyric acid } \\
\text { (GABA) }\end{array}$ & $\begin{array}{l}\text { Foods and pharmaceutical } \\
\text { products }\end{array}$ & Escherichia coli & $\begin{array}{l}\text { WJ008 } \\
+ \text { GadB mutant } \\
\text { (Glu89GIn/ } 4452- \\
466 \\
\text { gene) }\end{array}$ & 9.4 & - & - & $\begin{array}{l}\text { Choi et al., } \\
2015\end{array}$ \\
\hline$\beta$-ketothiolase (PhaA), & $\begin{array}{l}\text { Poly- } \\
\text { hydroxyalkanoate } \\
(\mathrm{PHA})\end{array}$ & Alternative to plastics & Ralstonia eutropha & $\begin{array}{l}\text { ATCC13869 } \\
+ \text { PhaA + PhaB } \\
+ \text { PhaC }\end{array}$ & 6 & - & - & $\begin{array}{l}\text { Matsumoto } \\
\text { et al., } 2011\end{array}$ \\
\hline \multicolumn{9}{|l|}{$\begin{array}{l}\mathrm{NADPH} \text {-dependent } \\
\text { acetoacetyl-CoA } \\
\text { reductase (PhaB), } \mathrm{P}(3 \mathrm{HB}) \\
\text { synthase (PhaC), }\end{array}$} \\
\hline $\begin{array}{l}\text { L-ornithine } \\
\text { decarboxylase (SpeC) }\end{array}$ & $\begin{array}{l}\text { 1,4-Diaminobutane } \\
\text { (putrescine) }\end{array}$ & $\begin{array}{l}\text { Precursor of L-arginine and } \\
\text { L-ornithine biosynthesis }\end{array}$ & Escherichia coli & $\begin{array}{l}\text { ATCC13032 } \\
\Delta \text { argR } \triangle \operatorname{argF}+ \\
\text { SpeC }+ \\
\text { 5'21-ArgF } \\
\text { (synthetic } \\
\text { 5'-region) }\end{array}$ & 19 & 0.55 & 0.16 & $\begin{array}{l}\text { Schneider } \\
\text { et al., } 2012\end{array}$ \\
\hline \multicolumn{9}{|l|}{ D. RARE SUGARS } \\
\hline $\begin{array}{l}\text { Rhamnulose- } 1 \text { - } \\
\text { phosphate aldolase } \\
\text { (RhaD) }\end{array}$ & D-Sorbose & $\begin{array}{l}\text { Food additives, cancer cell } \\
\text { suppressors, and building } \\
\text { blocks for anticancer, and } \\
\text { antiviral drug }\end{array}$ & Escherichia coli & $\begin{array}{l}\text { SY6 } \\
+ \text { RhaD + YqaB } \\
\text { (lac promoter) }\end{array}$ & 19.5 & - & - & $\begin{array}{l}\text { Yang et al., } \\
2015\end{array}$ \\
\hline $\begin{array}{l}\text { Fructose-1-phosphatase } \\
\text { (YqaB) }\end{array}$ & D-Psicose & $\begin{array}{l}\text { Food additives, cancer cell } \\
\text { suppressors, and building } \\
\text { blocks for anticancer, and } \\
\text { antiviral drug }\end{array}$ & Escherichia coli & $\begin{array}{l}\text { SY6 } \\
+ \text { RhaD + YqaB } \\
\text { (lac promoter) }\end{array}$ & 13.4 & - & - & $\begin{array}{l}\text { Yang et al., } \\
2015\end{array}$ \\
\hline $\begin{array}{l}\text { D-galactose isomerase } \\
\text { (D-Gal) }\end{array}$ & D-Tagatose & Functional sweetener & $\begin{array}{l}\text { Geobacillus } \\
\text { thermodenitrificans }\end{array}$ & $\begin{array}{l}\text { PICG } \\
\text { (Permeabilized } \\
\text { and immobilized) } \\
\text { + D-Gal }\end{array}$ & 165 & 55 & 0.55 & $\begin{array}{l}\text { Shin et al., } \\
2016\end{array}$ \\
\hline $\begin{array}{l}\text { GDP-D-mannose-4,6- } \\
\text { dehydratase (Gmd), } \\
\text { GDP-4-keto-6-deoxy-D- } \\
\text { mannose-3,5- } \\
\text { epimerase-4-reductase } \\
\text { (ManB), } \\
\text { Phosphomanno-mutase } \\
\text { (WcaG), } \\
\text { GTPmannose-1- } \\
\text { phosphate } \\
\text { guanylyl-transferase } \\
\text { (ManC) }\end{array}$ & $\begin{array}{l}\text { Guanosine } \\
\text { 50-diphosphate } \\
\text { (GDP)-L-fucose }\end{array}$ & $\begin{array}{l}\text { Precursor of } \\
\text { fucosyl-oligosaccharides }\end{array}$ & Escherichia coli & $\begin{array}{l}\text { ATCC13032 } \\
\text { Gmd + WcaG + } \\
\text { ManB + ManC }\end{array}$ & 0.086 & 0.001 & - & $\begin{array}{l}\text { Chin et al., } \\
2013\end{array}$ \\
\hline \multicolumn{9}{|l|}{ E. ALCOHOL } \\
\hline $\begin{array}{l}\text { Pyruvate decarboxylase } \\
\text { (Pdc), Alcohol } \\
\text { dehydrogenase (AdhB) }\end{array}$ & Ethanol & Alternative transportation fuel & Zymomonas mobilis & $\begin{array}{l}\mathrm{R} \\
\Delta / d h A \Delta p p c+ \\
\mathrm{Pgi}+\mathrm{PfkA}+ \\
\mathrm{GapA}+\mathrm{Pyk}+ \\
\mathrm{Glk}+\mathrm{Fba}+\mathrm{Tpi} \\
+\mathrm{Pdc}+\mathrm{AdhB}\end{array}$ & 119 & 2.3 & 0.48 & $\begin{array}{l}\text { Jojima et al., } \\
2015\end{array}$ \\
\hline
\end{tabular}

can be expressed on the surface is limited (Li, 2000). For example, foreign proteins that can be expressed in M13 phages have a length of $6.6 \mathrm{~nm}$ (Lee et al., 2012), while most enzymes are more than $10 \mathrm{~nm}$ in diameter (http://book.bionumbers.org/how-bigis-the-average-protein).

To address this problem, microbial cell surface display systems have been developed (i.e., C. glutamicum is 2,000-6,000 $\mathrm{nm}$ in length and $500 \mathrm{~nm}$ in diameter). Microbial cell surface display is generally accomplished by expressing a passenger protein on the cell surface fused with preexisting microbial surface proteins or with anchoring motifs of the membrane protein (Figure 1).
A C-terminal fusion, N-terminal fusion, or sandwich fusion strategy can be considered, depending on the characteristics of the fixed motif and the target protein. A good anchoring motif should meet the following requirements: (1) the premature fusion protein must have an efficient signal peptide or transport signal to pass through the inner membrane, (2) an anchoring motif must have a strong immobilization structure to retain the fusion protein on the cell surface, (3) an anchoring motif must be compatible with the inserted or fused foreign sequences (i.e., the anchoring motif should not become unstable following the insertion or fusion of heterologous sequences), and (4) 
A

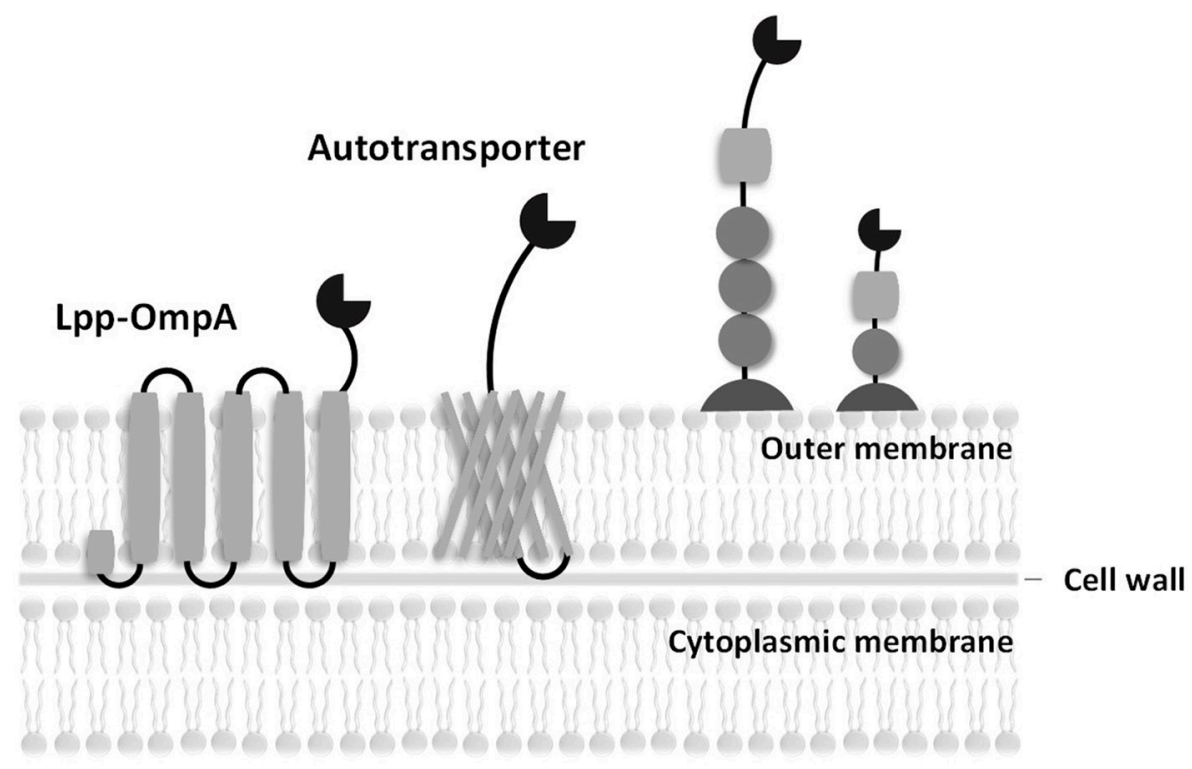

B

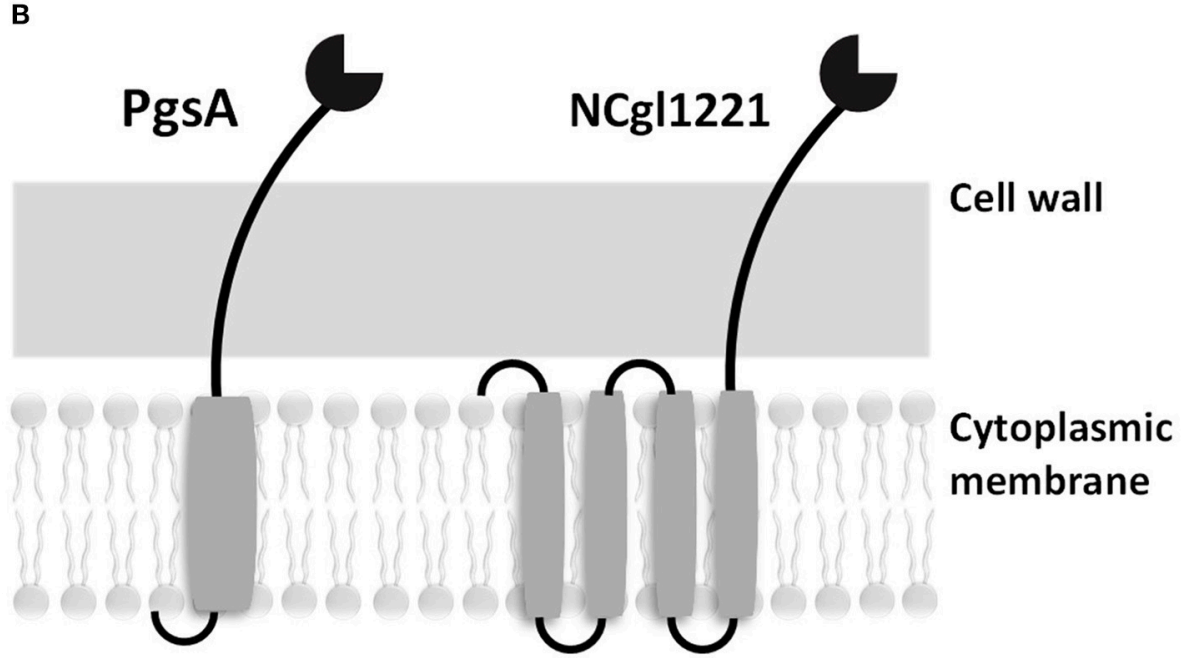

FIGURE 1 | Schematic diagrams of surface displayed enzymes in bacteria. (A) Surface display systems of gram-negative bacteria. (B) Surface display systems of gram-positive bacteria.

an anchoring motif must be resistant to attack by proteases present in the periplasmic space or media. In cell display systems, the properties of the target protein are known to significantly affect transport to the cell surface. In particular, the folded structure of the target protein (e.g., a disulfide bridge) in the outer membrane (the periplasmic side) can affect the movement of the target protein (Maurer et al., 1997). In addition, the insertion of amino acid sequences that contain multiple charged residues or hydrophobic residues within the target protein can result in ineffective sequence secretion in bacterial hosts.
Good hosts for surface display should be compatible with the expressed protein and should be easily culturable without cell lysis. In addition, the host cells must have a low extracellular protease activity. Gram-negative bacteria, including Escherichia coli, have a complex surface structure, which consists of the cytoplasmic membrane, periplasm, outer membrane, and many anchoring motifs that have been developed based on the outer membrane proteins. Therefore, the anchoring motif fused with the target protein in gram-negative bacterial hosts must be transferred to the outer membrane through the cytoplasmic membrane and periplasm. On the other hand, 
gram-positive bacteria are considered to be more suitable for whole-cell catalysts and whole-cell adsorbents because of the robust structure of their cell walls. Many surface proteins can be covalently immobilized on the cell walls of Bacillus spp., Staphylococcus spp., and C. glutamicum. A eukaryotic GRAS host, Saccharomyces cerevisiae, has protein folding and secretion systems that are similar to those in mammalian cells; it has been reported that mammalian proteins could be linked to the cell wall via a glycosylphosphatidylinositol (GPI) anchor or disulfide bonds (Lee et al., 2003).

\section{Examples of Surface-Displayed System in C. glutamicum}

The use of C. glutamicum, an important industrial biochemical producer and as a Gram-positive bacterial host, is advantageous in a cell surface display system because of the presence of various enzymes on the surface of C. glutamicum cells that extend the range of carbon sources during the production of biochemicals (Table 2). Starch is used as an industrial carbon source for microorganisms; however, C. glutamicum cannot consume starch directly. Starch should be provided in a hydrolyzed form using $\alpha$ amylase or glucoamylase. Tateno et al. have described the use of starch as a carbon source directly by a surface-displayed enzyme on C. glutamicum (Tateno et al., 2007). PgsA, a transmembrane protein derived from Bacillus subtilis, is a part of the poly$\gamma$-glutamate synthetase complex. It was used to anchor the $\alpha$-amylase from Streptococcus bovis 148 on the cell surface. The resulting display system was able to produce L-lysine (yield of $6.04 \mathrm{~g} / \mathrm{L}_{\text {medium}}$ ) from starch. In addition, a system displaying $\alpha$-amylase fused with PgsA as an anchor produced $6.4 \%$ of poly- $\beta$-hydroxybutyrate (PHB) (Song et al., 2013) in a metabolically engineered C. glutamicum, using starch as raw material.

In addition to PgsA, porin has been used as an anchor protein in C. glutamicum. Porin is a cell wall-related protein of C. glutamicum that is present in the mycolic acid layer. Adachi et al. have produced $1.08 \mathrm{~g} / \mathrm{L}_{\text {medium }}$ of L-lysine from a cellobiose carbon source using a system in which $\beta$-glucosidase was displayed using PorC as an anchor protein (Adachi et al., 2013). In addition, Imao et al. have reported the display of $\beta$-xylosidase on the cell surface using PorH as an anchor protein (Imao et al., 2017). In this expression system, xylooligosaccharides were used as a carbon source to produce $0.12 \mathrm{~g} / \mathrm{L}_{\text {medium }}$ of 1,5-diaminopentane (cadaverine).

The use of other anchor proteins has also been reported by Yao et al. They displayed S. bovis $148 \alpha$-amylase on the cell surfaces using the C-terminally truncated NCgl1221 anchor protein. In this system, $19.3 \mathrm{~g} / \mathrm{L}_{\text {medium }}$ of L-glutamate was produced from starch (Yao et al., 2009).

Recent reports of Choi et al. suggested that the proteins from 19 known mycolic acid layers in the extracellular membrane of C. glutamicum can be used as anchoring motifs in surface display systems (Choi et al., 2018). The $\alpha$-amylase of $S$. bovis was screened using a portion of NCgl1337 as an anchoring motif; this portion has a signal peptide and a predicted $\mathrm{O}$ mycoloylation site. As a result, $10.8 \mathrm{~g} / \mathrm{L}_{\text {medium }}$ of L-lysine was obtained from starch; this result demonstrates the potential of whole-cell biotransformation using the cell membrane proteins of C. glutamicum.

\section{SECRETIONS OF PROTEINS FROM C. glutamicum \\ Characteristics of Natural Secretion Systems in C. glutamicum}

The direct secretion of proteins into the culture medium by C. glutamicum over protein expression in the cytosol has several advantages. First, it is easy to obtain the target protein by purification because it does not require cell disruption and there are fewer proteins in the culture medium than in the cytoplasm (Nguyen et al., 2007). In addition, the oxidative environment of the extracellular culture fluid is suitable for the formation of disulfide bonds, which leads to protein folding and the expression of the active protein form (Makrides, 1996). Furthermore, the low extracellular protease activity of C. glutamicum contributes to the stability of the target proteins (Suzuki et al., 2009).

Two major translocation pathways have been known identified in C. glutamicum: the secretory (Sec)-pathway and the twin-arginine translocation (Tat)-pathway. The Secpathway transports unfolded proteins, whereas the Tat-pathway transports folded proteins (Kudva et al., 2013). These two pathways have the signal peptides necessary for the protein to pass through the cell membrane (von Heijne, 1985). The difference between the signal peptides of the two pathways is that the N-region of the Tat-type signal peptide is longer than that of the Sec-type signal peptide because the Tat-type signal peptide contains a conserved twin-arginine residue $(\mathrm{RR})$ at the end of the N-region (Berks et al., 2000; Figure 2A).

The Sec-pathway is a system that secretes proteins in an unfolded state (Figure 2B). Sec-dependent protein secretion systems have a co-translational targeting system and a posttranslational targeting system (Fröderberg et al., 2004). In the co-translational targeting system, the signal recognition particle (SRP) binds to the nascent peptide and leads the complex (nascent peptide + ribosome) to a membrane protein FtsY along with ribosomes; then, this SPR subsequently leads the nascent peptide to the channel complex (SecYEG). In the posttranslational targeting system, the translation-finished peptide binds to SecB and SecA to reach the SecYEG channel (Singh et al., 2014). Once the linear peptide passes through the SecYEG channel, the signal peptide is cleaved by Type I signal peptidase and the protein is released from the membrane (Schallenberger et al., 2012).

The Tat-pathway is a twin-arginine translocation pathway with a conserved twin-arginine motif (RR) in the signal peptide (Figure 2C). The basic structure of the Tat system is divided into two complexes: a docking complex and a pore complex. The docking complex (TatB and TatC) recognizes the $\mathrm{RR}$ motif of the Tat signal peptide in the folded protein. Then, the folded protein is translocated across the active pore complex (TatA), with a structural change of the docking complex (Goosens et al., 2015). 


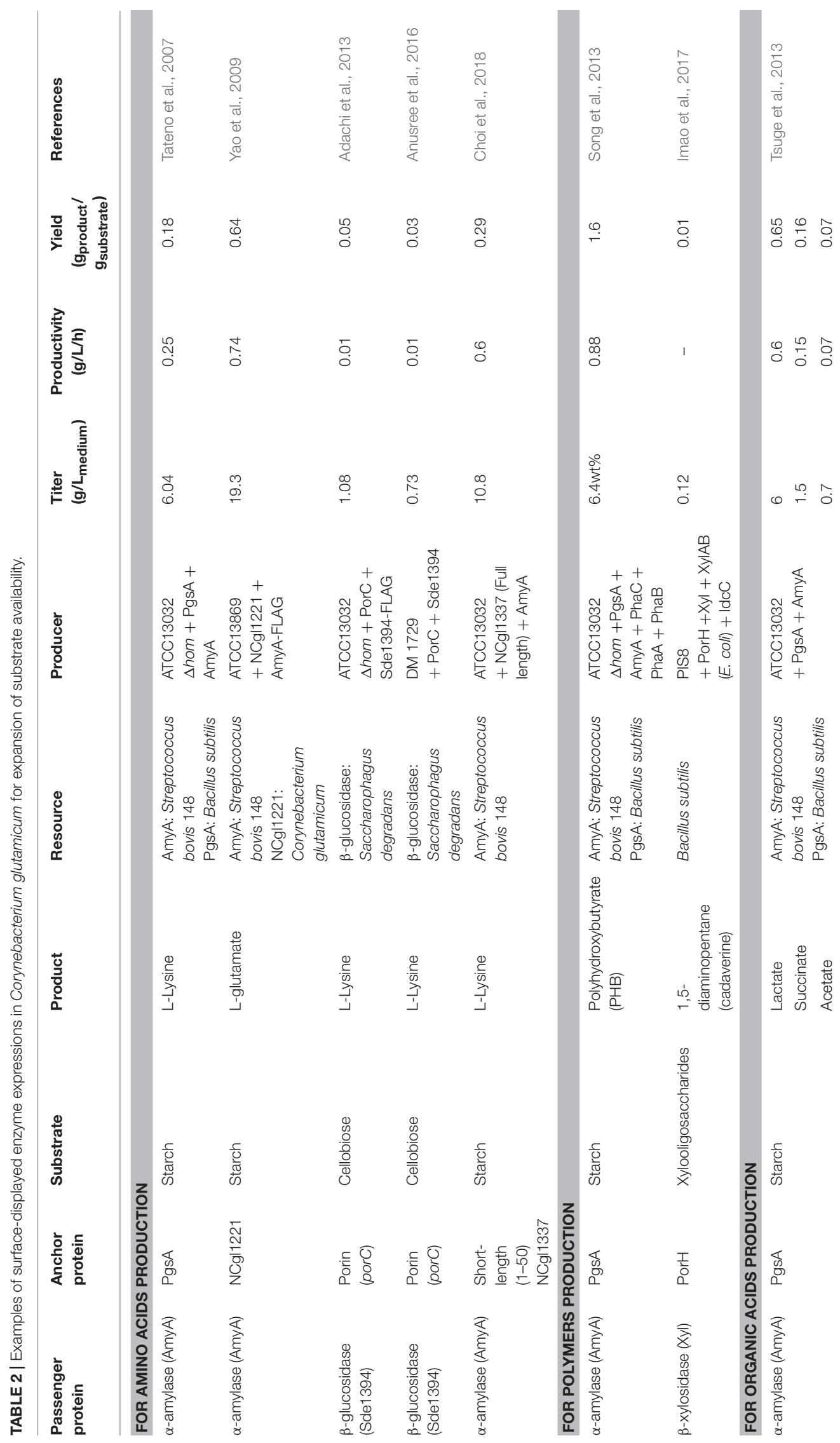




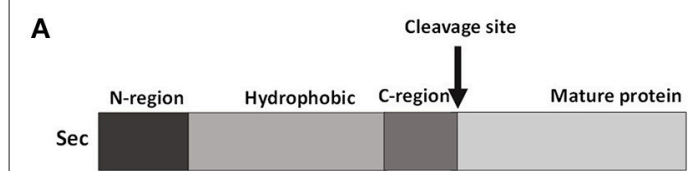

CsPA $_{C \text {.a }}$ MKRMKSLAAALTVAGAMLAAPVATA

PorB $_{\mathrm{c.g}}$ MKLSHRIAAMAATAGITVAAFAAPASA
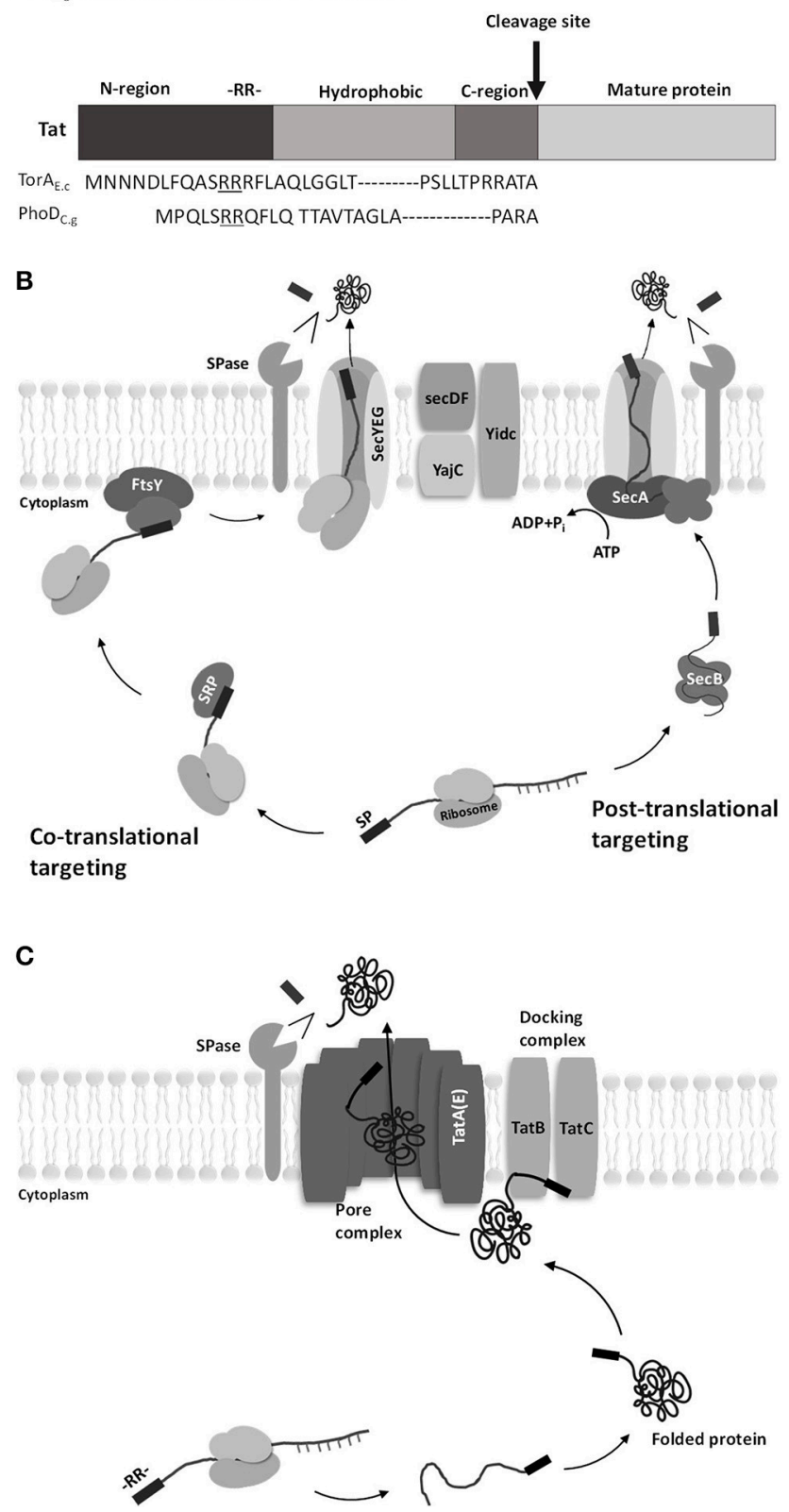

FIGURE 2 | Diagrams of signal peptides for Sec pathway and Tat pathway in C. glutamicum. (A) General structure and amino acid sequence of the Secand Tat-type signal peptides. The signal peptide consists of three regions: the amino-terminal region ( $\mathrm{N}$-region), the hydrophobic region, and the

carboxy-terminal region (C-region). The difference between the two pathways is that the $\mathrm{N}$-region of the twin-arginine translocation (Tat)-type signal peptide is longer than the secretory (Sec)-type signal peptide because the Tat-type signal peptide contains a conserved twin-arginine residue (RR) at the end of the $\mathrm{N}$-region $\left[\mathrm{CspA}_{\mathrm{C} . \mathrm{a}}\right.$, surface $(\mathrm{S})$-layer protein from Corynebacterium

(Continued)
FIGURE 2 | ammoniagenes; PorB ${ }_{\mathrm{C} . g}$, porinB from C. glutamicum; Tor $\mathrm{A}_{\mathrm{E} . \mathrm{C}}$, TMAO reductase from Escherichia coli; $\mathrm{PhoD}_{\mathrm{C} . \mathrm{g}}$, alkaline phosphatase from C. glutamicum] (Berks et al., 2000). (B) Protein translocation by the Sec pathway. Sec translocase consists of the following components: SecYEG, a core protein in Sec translocase that forms the transmembrane protein-conducting channel (PCC), and SecDF, interacts with YajC to improve protein transport efficiency driven by the proton motive force (Scotti et al., 1999). In the co-translational targeting Sec pathway, signal recognition particles (SRPs) bind to the signal peptide at the beginning of translation where proteins are still bound to ribosomes. Then, the SRPs and the initial ribosomal protein (nascent protein) migrate to the SRP receptor and membrane protein FtsY and subsequently come in contact with SecYEG. The nascent protein passes through SecYEG while the ribosome is attached. In the post-translational targeting Sec pathway, a translation-finished protein binds to SecB without ribosome and then migrates to SecA-SecYEG complex. The delivered protein then passes through SecYEG while SecA is attached. (C) Protein translocation by the Tat pathway. The Tat system consists of TatA-like proteins (TatA, TatB, and TatE) and TatC (TatE seems to have the same function as TatA, though the difference is not clear yet). Translocation begins when the folded cargo proteins interact with the docking complex. The twin-arginine (RR) motif of the Tat signal peptide attaches to the signal peptide-binding loop of TatBC. The docking complex recognizes the cargo protein and inserts it into the membrane. TatA receives the cargo protein from the docking complex, and the cargo protein is translocated across the active pore complex. The signal peptide is then cleaved by type I signal peptidase, and the mature protein is separated from the cell membrane (Tuteja, 2005).

\section{Examples of Recombinant Protein Secretion in C. glutamicum}

The production of a recombinant protein in C. glutamicum by a protein secretion system (the secretion of $\alpha$-amylase from Bacillus amyloliquefaciens using the Sec system) was first reported by Smith et al. (Smith et al., 1986). Subsequently, protease, transglutaminase, green fluorescent protein (GFP), subtilisin, and endoglucanase have been produced in the C. glutamicum secretion system (Table 3 ).

Some studies have shown that eukaryotic proteins (such as human or camelid proteins) and microbial proteins could be successfully expressed in C. glutamicum. Yim et al. produced $68 \mathrm{mg} / \mathrm{L}_{\text {medium }}$ of a single-chain variable fragment $(\mathrm{scFv})$ with anthrax toxin as an antigen in a Sec system by codon optimization using a strong promoter (Yim et al., 2014). When the same M18 scFv was expressed in E. coli, a slightly higher level of the protein was obtained $\left(89.8 \mathrm{mg} / \mathrm{L}_{\text {medium }}\right)$. Nevertheless, the use of C. glutamicum may be safer for drugs such as antibodies because endotoxins are not produced by a GRAS host, unlike the case of $E$. coli, and the secreted proteins are stable because there is no extracellular protease activity. Grampositive bacteria such as C. glutamicum have no outer membrane; thus, target proteins need to pass through only one membrane to move out of the cell (van Wely et al., 2001). In addition, yeast cells that can glycosylate proteins when producing fulllength antibodies are mainly used. However, in contrast to the glycosylation system of mammalian cells, yeast cells have a mannose-rich glycosylation system; thus, they are often not suitable for use in medicine. In particular, post-translational modifications such as glycosylation in Pichia pastoris often lead to unexpected protein structure and function (Dai et al., 
TABLE 3 | Examples of protein secretions in Corynebacterium glutamicum.

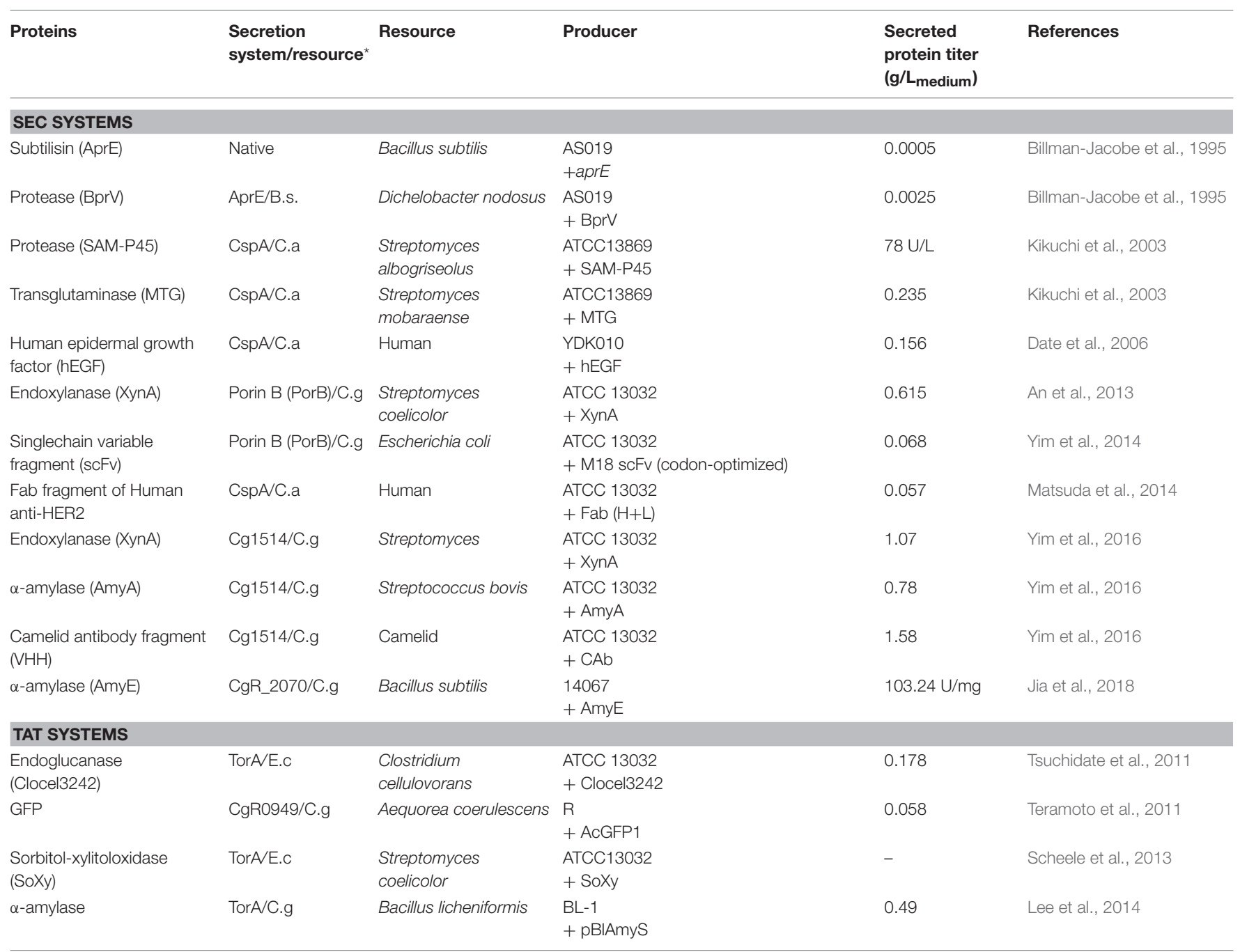

${ }^{\star}$ B.s, Bacillus subtilis; C.a, Corynebacterium ammoniagenes; C.g, Corynebacterium glutamicum; E.c, Escherichia coli.

2015). Nevertheless, C. glutamicum may be advantageous as a host for the expression of antibody fragments such as the scFv and Fab (antigen-binding fragment), which do not require glycosylation (Yim et al., 2014). Matsuda et al. produced 57 $\mathrm{mg} / \mathrm{L}_{\text {medium }}$ of an $\mathrm{Fab}$ fragment of anti-human epidermal growth factor receptor 2 (anti-HER2) using the Sec-secretion system with a cell wall protein-deficient C. glutamicum strain (Matsuda et al., 2014). This was based on the formation of an intermolecular disulfide bond when the heavy and light subunits of anti-HER2 Fab fragments were present at the same time. In another study, Date et al. reported the production of $156 \mathrm{mg} / \mathrm{L}_{\text {medium }}$ of an active human epidermal growth factor (hEGF) with six cysteine residues that form three disulfide bonds, using the Sec-secretion system in C. glutamicum (Date et al., 2006). Therefore, C. glutamicum is an attractive secretory expression host for the production of medicinal proteins containing disulfide bonds as well as heterologous enzymes.
Efforts have also been made to introduce new signal peptides in C. glutamicum. An analysis of the secretion of C. glutamicum at high cell densities showed that the most abundant protein (51\% of extracellular proteins) in the culture supernatant was a hypothetical protein encoded by $c$ g1514. Using the promoter and signal peptide of the Cg1514 protein, three target proteins [endocolanicol A, $1.07 \mathrm{~g} / \mathrm{L}_{\text {medium; }}$ S. bovis $\alpha$-amylase, $0.78 \mathrm{~g} / \mathrm{L}_{\text {medium; }}$; camelid antibody fragment (VHH) for human lysozyme, 1.58 $\mathrm{g} / \mathrm{L}_{\text {medium }}$ ] were produced (Yim et al., 2016). These results suggest that Cg1514-derived expression and secretion signals may be particularly effective in the production of secretory proteins from C. glutamicum.

Although not as common as the Sec system, there have been attempts to secrete proteins such as GFP or $\alpha$-amylase using the Tat system in C. glutamicum. In particular, the Tat system is sometimes necessary because protein folding and the insertion of some cofactors into the proteins must occur in the cytoplasm. As the Tat system can transduce the substrates in a 
TABLE 4 | Examples of inducible and constitutive promoters in Corynebacterium glutamicum.

\begin{tabular}{|c|c|c|}
\hline Promoter & Description & References \\
\hline \multicolumn{3}{|l|}{ INDUCIBLE PROMOTERS } \\
\hline $\mathrm{P}_{\text {lac UV5 }}$ & IPTG inducible promoter & Brabetz et al., 1991 \\
\hline$P_{\text {trc }}$ & IPTG inducible promoter & Kirchner and Tauch, 2003 \\
\hline$P_{p r p B}$ & Propionate inducible promoter & Lee and Keasling, 2006 \\
\hline$P_{\mathrm{CJ} 10 \times 2}$ & $42^{\circ} \mathrm{C}$ inducible promoter & Park et al., 2008 \\
\hline $\mathrm{P}_{\text {tac }-\mathrm{M}}$ & Derived from the tac promoter, IPTG inducible promoter & Xu et al., 2010 \\
\hline$P_{\text {malE1 }}, P_{\text {git } 1}$ & Maltose, Gluconate inducible promoter & Okibe et al., 2010 \\
\hline$P_{B A D}$ & Arabinose inducible promoter & Zhang et al., 2012 \\
\hline SPLS & Synthetic promoter libraries, IPTG-inducible & Rytter et al., 2014 \\
\hline PaprE & Promoter of Bacillus subtilis subtilisin (aprE) & Billman-Jacobe et al., 1995 \\
\hline$P_{180}$ & Isolated promoter from Corynebacterium glutamicum genome library & Park et al., 2004 \\
\hline$P_{\text {sod }}$ & Promoter of sod gene, encoding superoxide dismutase & Becker et al., 2005 \\
\hline $\mathrm{P}_{\text {dapA }}$ & Promoter of dapA gene, not known to be prone to transcriptional control & van Ooyen et al., 2012 \\
\hline$P_{\text {porB }}$ & Promoter of porB gene, encoding porin B in Corynebacterium glutamicum & An et al., 2013 \\
\hline $\mathrm{P}_{i l / V C}$ & Promoter of ilvC gene, encoding ketol-acid reductoisomerase & Kang et al., 2014 \\
\hline$P_{\mathrm{L} 10}, P_{\mathrm{L} 26}, P_{116}, P_{151}, P_{H 30}, P_{H 36}$ & $\begin{array}{l}\text { Fully synthetic promoter library consisting of } 70-b p \text { random sequences in } \\
\text { Corynebacterium glutamicum }\end{array}$ & Yim et al., 2013; Oh et al., 2015 \\
\hline
\end{tabular}

TABLE 5 | Examples of expression vectors in C. glutamicum.

\begin{tabular}{|c|c|c|c|c|c|c|c|}
\hline Vector & Size (kb) & Replicon & $\begin{array}{l}\text { Copy number } \\
\text { per cell }\end{array}$ & $\begin{array}{l}\text { Selection } \\
\text { marker }\end{array}$ & $\begin{array}{l}\text { Promoter, regulatory } \\
\text { gene }\end{array}$ & $\begin{array}{l}\text { Induction } \\
\text { conditions } \\
\text { (Conc.) }\end{array}$ & References \\
\hline pXMJ19 & 6.6 & pBL1 & $10-30$ & $\mathrm{Cm}^{r}$ & $P_{t a c}, l a c l^{q}$ & IPTG (1 mM) & $\begin{array}{l}\text { Anglana and } \\
\text { Bacchetti, } 1999\end{array}$ \\
\hline pBKGEXm2 & 7.3 & $\mathrm{pBL} 1$ & $10-30$ & $\mathrm{Km}^{r}$ & $P_{\text {tac }}$, lac/ $/ q$ & IPTG (1 mM) & $\begin{array}{l}\text { Srivastava and Deb, } \\
2002\end{array}$ \\
\hline pCRA429 & 4.3 & $\mathrm{pBL} 1$ & $10-30$ & $\mathrm{Cm}^{r}$ & $\mathrm{P}_{\text {tac }}$ & Constitutive & Suzuki et al., 2009 \\
\hline pDXW-8 & 9.6 & $\mathrm{pBL1}$ & $10-30$ & $\mathrm{Km}^{r}$ & $\mathrm{P}_{\text {tac }}$, lac/PF104 & IPTG (1 mM) & Xu et al., 2010 \\
\hline pEC901 & 8.5 & pCG1 & 30 & $\mathrm{Km}^{r}$ & $P_{L} / P_{R}(\lambda), c \mid 857$ & $40^{\circ} \mathrm{C}$ & $\begin{array}{l}\text { Makoto Tsuchiya, } \\
1988\end{array}$ \\
\hline pZ8-1 & 7.0 & pCG1 & 30 & $\mathrm{Km}^{r}$ & $\mathrm{P}_{\text {tac }}$ & Constitutive & Dusch et al., 1999 \\
\hline pTRCmob & 6.4 & pGA1 & 30 & $\mathrm{Km}^{r}$ & Ptrc & $\begin{array}{l}\text { IPTG }(0.2 \\
\text { g/Lmedium })\end{array}$ & Liu et al., 2007 \\
\hline pAPE12 & 4.6 & pNG2 & $<10$ & $\mathrm{Km}^{\mathrm{r}}$ & $\mathrm{P}_{\mathrm{tac}}, \mid \mathrm{ac} / \mathrm{q}$ & $\begin{array}{l}\text { IPTG }(0.15 \\
\text { g/Lmedium })\end{array}$ & Guillouet et al., 1999 \\
\hline
\end{tabular}


fully collapsed state through the cytoplasmic membrane, the use of the Tat-pathway for enzyme secretion has been investigated. To this end, FAD cofactor-containing sorbitol-xylitol oxidase (SoXy), which is a cytosolic enzyme of Streptomyces coelicolor, was expressed in C. glutamicum using the Tat secretion system (Scheele et al., 2013). This study demonstrated that heterologous proteins containing cofactors can also be produced using the C. glutamicum secretion system.

\section{GENETIC TOOLS FOR PROTEIN EXPRESSION IN C. glutamicum}

To express recombinant proteins efficiently for the amino acid, food, and pharmaceutical industries, it is necessary to precisely control the expression of genes and to optimally control the metabolic flow toward the target protein or amino acid. Therefore, to produce the target protein efficiently, it is important to do the following: (1) optimize the promoter to increase expression efficiency, (2) construct a plasmid vector for various kinds of proteins, (3) construct an efficient protein-secretion pathway, and (4) design a C. glutamicum bioreactor culture system for high-yield production.

There have been attempts to increase the yield of expression systems, by using promoters (Table 4), which are mainly used for the production of amino acids and industrial enzymes with C. glutamicum as a host. The selection of optimal promoter and regulatory sequences is essential for producing useful products in living organisms. Promoters that are mainly used in C. glutamicum include several inducible promoters such as $\mathrm{P}_{\text {lacUV5 }}, \mathrm{P}_{\text {tac }}, \mathrm{P}_{\text {trp }}, \mathrm{P}_{\text {araBAD }}, \mathrm{P}_{\text {trc }}$, and the phage $\mathrm{P}_{\mathrm{R}} / \mathrm{P}_{\mathrm{L}}$ promoter from E. coli (Rytter et al., 2014). However, due to the low isopropyl- $\beta$-D-thiogalactopyranoside (IPTG) permeability of C. glutamicum, an IPTG-inducible expression system would have a lower expression level in C. glutamicum than in E. coli. Therefore, studies have been carried out to improve the promoter core sequence and membrane permeability of C. glutamicum and to increase gene expression by the site-directed mutagenesis. For example, a single-site mutation of the wild-type lac promoter has been used to enhance its protein expression level (Brabetz et al., 1991). In addition, the tac-M primer for constructing the tac promoter was found to increase the promoter activity following a mutation at the -10 region (Xu et al., 2010).

An auto-inducible promoter is a promoter that expresses proteins according to variables such as the nutrient type/concentration, oxygen level, $\mathrm{pH}$ level, and cell growth stage (Chou et al., 1995); this is advantageous for producing recombinant proteins on an industrial scale. Kim et al. (2016) engineered the SigB-dependent cg3141 promoter in C. glutamicum to develop an auto-inducible promoter system that is capable of expressing recombinant proteins during the transition phase between the log phase and the stationary phase of the cells. As a result, the model protein, glutathione S-transferase, was successfully produced on a lab-scale bioreactor (5 L) by introducing the $\mathrm{P}_{4-\mathrm{N} 14}$ promoter (Kim et al., 2016).

The use of constitutive promoters is advantageous because they do not require expensive reagents for induction or optimized induction conditions (Yim et al., 2013). Constitutive promoters derived from the genome of $C$. glutamicum, such as $\mathrm{P}_{\text {sodA }}$, $\mathrm{P}_{\text {gap } A}, \mathrm{P}_{\text {eftu }}$, and $\mathrm{P}_{c s p B}$, are known to have high expression levels. However, the strength of the promoters cannot be directly compared and the use of strong promoters can also be affected by other genetic elements such as the $5^{\prime}$-untranslated region (5'-UTR) (Teramoto et al., 2011) and transcription initiation region (TIR) (Yim et al., 2013). Therefore, the selection of an optimal promoter is required because a strong promoter alone does not guarantee high protein expression. Yim et al. have developed the first synthetic promoter in C. glutamicum (Yim et al., 2013). Sequences including $\mathrm{P}_{\mathrm{L} 10}, \mathrm{P}_{\mathrm{L} 26}, \mathrm{P}_{\mathrm{I} 16}, \mathrm{P}_{\mathrm{I} 51}, \mathrm{P}_{\mathrm{H} 30}$, and $\mathrm{P}_{\mathrm{H} 36}$ were selected from the promoter library, which consisted of 70 randomly chosen nucleotide sequences. Among them, $\mathrm{P}_{\mathrm{H} 36}$ was the strongest promoter, and it successfully induced the expression of antibody fragments and endoxylanase (746 $\mathrm{mg} / \mathrm{L}_{\text {medium }}$ ), as model proteins. Appropriate expression vectors and promoters are also important for increasing the yield of recombinant proteins. Currently, several C. glutamicum-E. coli shuttle expression vectors are being widely used (Table 5).

\section{CONCLUSION}

C. glutamicum can be used as an industrial L-glutamate and L-lysine producer. In addition, various types of recombinant proteins can be expressed in C. glutamicum, which has been used for several decades for the production of microbial enzyme. Furthermore, C. glutamicum has been used to increase yields, develop new anchoring systems, and signal peptides (for the efficient production of biochemicals and nutraceuticals, enzymes, medicinal proteins, and biopolymers), and screen synthetic promoters of various strengths. However, using C. glutamicum as an expression host has several disadvantages when compared with using E. coli as an expression host: (1) a much lower transformation efficiency, (2) fewer available expression systems, and (3) lower yields for some proteins, especially antibodies. Therefore, further studies are necessary to develop various tools to enhance protein yields and reduce manufacturing costs. Recent advances in bioinformatics, such as next-generation sequencing (NGS), RNA-seq, and proteomics, would provide more information on the protein production pathways in C. glutamicum.

\section{AUTHOR CONTRIBUTIONS}

ML wrote the manuscript and PK supervised. All authors have made intellectual contributions to the work, and approved it for publication.

\section{ACKNOWLEDGMENTS}

This work was financially supported by the grants from the National Research Foundation of Korea (2016R1E1A1A01943552). The authors extend their appreciation to the A3 Foresight Program (2016K2A9A2A10005545) for supporting their travel. 


\section{REFERENCES}

Adachi, N., Takahashi, C., Ono-Murota, N., Yamaguchi, R., Tanaka, T., and Kondo, A. (2013). Direct L-lysine production from cellobiose by Corynebacterium glutamicum displaying beta-glucosidase on its cell surface. Appl. Microbiol. Biotechnol. 97, 7165-7172. doi: 10.1007/s00253-013-5009-4

An, S. J., Yim, S. S., and Jeong, K. J. (2013). Development of a secretion system for the production of heterologous proteins in Corynebacterium glutamicum using the Porin B signal peptide. Protein Expr. Purif. 89, 251-257. doi: 10.1016/j.pep.2013.04.003

Anglana, M., and Bacchetti, S. (1999). Construction of a recombinant adenovirus for efficient delivery of the I-SceI yeast endonuclease to human cells and its application in the in vivo cleavage of chromosomes to expose new potential telomeres. Nucleic Acids Res. 27, 4276-4281. doi: 10.1093/nar/27.2 1.4276

Anusree, M., Wendisch, V. F., and Nampoothiri, K. M. (2016). Co-expression of endoglucanase and beta-glucosidase in Corynebacterium glutamicum DM1729 towards direct lysine fermentation from cellulose. Bioresour. Technol. 213, 239-244. doi: 10.1016/j.biortech.2016.03.019

Aoki, T., Tahara, T., Fujino, H., and Watabe, H. (2002). "GFP-display," an easy detection method for single amino acid changes in a target polypeptide: application to random mutagenesis. Anal. Biochem. 300, 103-106. doi: 10.1006/abio.2001.5451

Bae, W., Chen, W., Mulchandani, A., and Mehra, R. K. (2000). Enhanced bioaccumulation of heavy metals by bacterial cells displaying synthetic phytochelatins. Biotechnol. Bioeng. 70, 518-524. doi: 10.1002/10970290(20001205)70:5\&lt;518::AID-BIT6\&gt;3.0.CO;2-5

Becker, J., Klopprogge, C., Zelder, O., Heinzle, E., and Wittmann, C. (2005). Amplified expression of fructose 1,6-bisphosphatase in Corynebacterium glutamicum increases in vivo flux through the pentose phosphate pathway and lysine production on different carbon sources. Appl. Environ. Microbiol. 71, 8587-8596. doi: 10.1128/AEM.71.12.8587-8596.2005

Berks, B. C., Sargent, F., and Palmer, T. (2000). The Tat protein export pathway. Mol. Microbiol. 35, 260-274. doi: 10.1046/j.1365-2958.2000.0 1719.x

Billman-Jacobe, H., Hodgson, A. L., Lightowlers, M., Wood, P. R., and Radford, A. J. (1994). Expression of ovine gamma interferon in Escherichia coli and Corynebacterium glutamicum. Appl. Environ. Microbiol. 60, 1641-1645.

Billman-Jacobe, H., Wang, L., Kortt, A., Stewart, D., and Radford, A. (1995). Expression and secretion of heterologous proteases by Corynebacterium glutamicum. Appl. Environ. Microbiol. 61, 1610-1613.

Boder, E. T., and Wittrup, K. D. (1997). Yeast surface display for screening combinatorial polypeptide libraries. Nat. Biotechnol. 15, 553-557. doi: $10.1038 /$ nbt0697-553

Brabetz, W., Liebl, W., and Schleifer, K. H. (1991). Studies on the utilization of lactose by Corynebacterium glutamicum, bearing the lactose operon of Escherichia coli. Arch. Microbiol. 155, 607-612. doi: 10.1007/BF00245357

Buchholz, J., Schwentner, A., Brunnenkan, B., Gabris, C., Grimm, S., Gerstmeir, R., et al. (2013). Platform engineering of Corynebacterium glutamicum with reduced pyruvate dehydrogenase complex activity for improved production of L-lysine, L-valine, and 2-ketoisovalerate. Appl. Environ. Microbiol. 79, 5566-5575. doi: 10.1128/AEM.01741-13

Bückle-Vallant, V., Krause, F. S., Messerschmidt, S., and Eikmanns, B. J. (2014). Metabolic engineering of Corynebacterium glutamicum for 2ketoisocaproate production. Appl. Microbiol. Biotechnol. 98, 297-311. doi: 10.1007/s00253-013-5310-2

Butenas, S. (2013). Comparison of natural and recombinant tissue factor proteins: new insights. Biol. Chem. 394, 819-829. doi: 10.1515/hsz-2012-0350

Chin, Y. W., Park, J. B., Park, Y. C., Kim, K. H., and Seo, J. H. (2013). Metabolic engineering of Corynebacterium glutamicum to produce GDP-Lfucose from glucose and mannose. Bioprocess Biosyst. Eng. 36, 749-756. doi: 10.1007/s00449-013-0900-z

Choi, J. W., Yim, S. S., and Jeong, K. J. (2018). Development of a potential protein display platform in Corynebacterium glutamicum using mycolic acid layer protein, NCgl1337, as an anchoring motif. Biotechnol. J. 13:1700509. doi: 10.1002/biot.201700509

Choi, J. W., Yim, S. S., Kim, M. J., and Jeong, K. J. (2015). Enhanced production of recombinant proteins with Corynebacterium glutamicum by deletion of insertion sequences (IS elements). Microb. Cell Fact. 14:207. doi: 10.1186/s12934-015-0401-7

Chou, C. H., Aristidou, A. A., Meng, S. Y., Bennett, G. N., and San, K. Y. (1995). Characterization of a $\mathrm{pH}$-inducible promoter system for high-level expression of recombinant proteins in Escherichia coli. Biotechnol. Bioeng. 47, 186-192. doi: 10.1002/bit.260470210

Cramer, A., Gerstmeir, R., Schaffer, S., Bott, M., and Eikmanns, B. J. (2006). Identification of RamA, a novel LuxR-type transcriptional regulator of genes involved in acetate metabolism of Corynebacterium glutamicum. J. Bacteriol. 188, 2554-2567. doi: 10.1128/JB.188.7.2554-2567.2006

Dai, M., Yu, C., Fang, T., Fu, L., Wang, J., Zhang, J., et al. (2015). Identification and functional characterization of glycosylation of recombinant human platelet-derived growth factor-BB in Pichia pastoris. PLoS ONE 10:e0145419. doi: 10.1371/journal.pone. 0145419

Date, M., Itaya, H., Matsui, H., and Kikuchi, Y. (2006). Secretion of human epidermal growth factor by Corynebacterium glutamicum. Lett. Appl. Microbiol. 42, 66-70. doi: 10.1111/j.1472-765X.2005.01802.x

Dhillon, J. K., Drew, P. D., and Porter, A. J. (1999). Bacterial surface display of an anti-pollutant antibody fragment. Lett. Appl. Microbiol. 28, 350-354. doi: 10.1046/j.1365-2672.1999.00552.x

Dusch, N., Puhler, A., and Kalinowski, J. (1999). Expression of the Corynebacterium glutamicum panD gene encoding L-aspartate-alphadecarboxylase leads to pantothenate overproduction in Escherichia coli. Appl. Environ. Microbiol. 65, 1530-1539.

Eikmanns, B. J., Kleinertz, E., Liebl, W., and Sahm, H. (1991). A family of Corynebacterium glutamicum/Escherichia coli shuttle vectors for cloning, controlled gene expression, and promoter probing. Gene 102, 93-98. doi: 10.1016/0378-1119(91)90545-M

Fröderberg, L., Houben, E. N., Baars, L., Luirink, J., and De Gier, J. W. (2004). Targeting and translocation of two lipoproteins in Escherichia coli via the SRP/Sec/YidC pathway. J. Biol. Chem. 279, 31026-31032. doi: 10.1074/jbc.M403229200

Goosens, V. J., De-San-Eustaquio-Campillo, A., Carballido-Lopez, R., and Van Dijl, J. M. (2015). A Tat menage a trois-The role of Bacillus subtilis TatAc in twin-arginine protein translocation. Biochim. Biophys. Acta 1853, 2745-2753. doi: 10.1016/j.bbamcr.2015.07.022

Guillouet, S., Rodal, A. A., An, G., Lessard, P. A., and Sinskey, A. J. (1999). Expression of the Escherichia coli catabolic threonine dehydratase in Corynebacterium glutamicum and its effect on isoleucine production. Appl. Environ. Microbiol. 65, 3100-3107.

Ikeda, M., and Katsumata, R. (1992). Metabolic engineering to produce tyrosine or phenylalanine in a tryptophan-producing Corynebacterium glutamicum strain. Appl. Environ. Microbiol. 58, 781-785.

Ikeda, M., and Katsumata, R. (1999). Hyperproduction of tryptophan by Corynebacterium glutamicum with the modified pentose phosphate pathway. Appl. Environ. Microbiol. 65, 2497-2502.

Imao, K., Konishi, R., Kishida, M., Hirata, Y., Segawa, S., Adachi, N., et al. (2017). 1,5-Diaminopentane production from xylooligosaccharides using metabolically engineered Corynebacterium glutamicum displaying beta-xylosidase on the cell surface. Bioresour. Technol. 245, 1684-1691. doi: 10.1016/j.biortech.2017.05.135

Jensen, J. V., and Wendisch, V. F. (2013). Ornithine cyclodeaminase-based proline production by Corynebacterium glutamicum. Microb. Cell Fact. 12:63. doi: $10.1186 / 1475-2859-12-63$

Jia, H. Li, H., Zhang, L., and Xu, D. (2018). Development of a novel gene expression system for secretory production of heterologous proteins via the general secretory (Sec) pathway in Corynebacterium glutamicum. Iran. J. Biotechnol. 16, 42-48. doi: 10.21859/ijb.1746

Jojima, T., Fujii, M., Mori, E., Inui, M., and Yukawa, H. (2010). Engineering of sugar metabolism of Corynebacterium glutamicum for production of amino acid L-alanine under oxygen deprivation. Appl. Microbiol. Biotechnol. 87, 159-165. doi: 10.1007/s00253-010-2493-7

Jojima, T., Noburyu, R., Sasaki, M., Tajima, T., Suda, M., Yukawa, H., et al. (2015). Metabolic engineering for improved production of ethanol by Corynebacterium glutamicum. Appl. Microbiol. Biotechnol. 99, 1165-1172. doi: 10.1007/s00253-014-6223-4

Kang, M. S., Han, S. S., Kim, M. Y., Kim, B. Y., Huh, J. P., Kim, H. S., et al. (2014). High-level expression in Corynebacterium glutamicum of nitrile hydratase 
from Rhodococcus rhodochrous for acrylamide production. Appl. Microbiol. Biotechnol. 98, 4379-4387. doi: 10.1007/s00253-014-5544-7

Kikuchi, Y., Date, M., Yokoyama, K., Umezawa, Y., and Matsui, H. (2003). Secretion of active-form Streptoverticillium mobaraense transglutaminase by Corynebacterium glutamicum: processing of the pro-transglutaminase by a cosecreted subtilisin-Like protease from Streptomyces albogriseolus. Appl. Environ. Microbiol. 69, 358-366. doi: 10.1128/AEM.69.1.358-3 66.2003

Kim, M. J., Yim, S. S., Choi, J. W., and Jeong, K. J. (2016). Development of a potential stationary-phase specific gene expression system by engineering of SigB-dependent cg3141 promoter in Corynebacterium glutamicum. Appl. Microbiol. Biotechnol. 100, 4473-4483. doi: 10.1007/s00253-016-7297-y

Kinoshita, S., Udaka, S., and Shimono, M. (1957). Studies on the amino acid fermentation Part I, production of L-glutamic acid by various microorganisms. J. Gen. Appl. Microbiol. 3, 193-205 doi: 10.2323/jgam.3.193

Kirchner, O., and Tauch, A. (2003). Tools for genetic engineering in the amino acid-producing bacterium Corynebacterium glutamicum. J. Biotechnol. 104, 287-299. doi: 10.1016/S0168-1656(03)00148-2

Kudva, R., Denks, K., Kuhn, P., Vogt, A., Muller, M., and Koch, H. G. (2013). Protein translocation across the inner membrane of Gram-negative bacteria: the Sec and Tat dependent protein transport pathways. Res. Microbiol. 164, 505-534. doi: 10.1016/j.resmic.2013.03.016

Kwong, S. C., and Rao, G. (1991). Utility of culture redox potential for identifying metabolic state changes in amino acid fermentation. Biotechnol. Bioeng. 38, 1034-1040. doi: 10.1002/bit.260380912

Lee, B. H., Lee, S. B., Kim, H. S., Jeong, K. J., Park, J. Y., Park, K. M., et al. (2015). Whole cell bioconversion of ricinoleic acid to 12 -ketooleic acid by recombinant Corynebacterium glutamicum-based biocatalyst. J. Microbiol. Biotechnol. 25, 452-458. doi: 10.4014/jmb.1501.01001

Lee, B. Y., Zhang, J., Zueger, C., Chung, W. J., Yoo, S. Y., Wang, E., et al. (2012), Virus-based piezoelectric energy generation. Nat. Nanotechnol. 7, 351-356. doi: 10.1038/nnano.2012.69

Lee, J., Sim, S. J., Bott, M., Um, Y., Oh, M. K., and Woo, H. M. (2014). Succinate production from $\mathrm{CO}(2)$-grown microalgal biomass as carbon source using engineered Corynebacterium glutamicum through consolidated bioprocessing. Sci. Rep. 4:5819. doi: 10.1038/srep05819

Lee, J. S., Shin, K. S., Pan, J. G., and Kim, C. J. (2000). Surface-displayed viral antigens on Salmonella carrier vaccine. Nat. Biotechnol. 18, 645-648. doi: $10.1038 / 76494$

Lee, J. Y., Na, Y. A., Kim, E., Lee, H. S., and Kim, P. (2016). Erratum to: The actinobacterium Corynebacterium glutamicum, an industrial workhorse. J. Microbiol. Biotechnol. 26:1341. doi: 10.4014/jmb.2016.2607.1341

Lee, S. K., and Keasling, J. D. (2006). A Salmonella-based, propionateinducible, expression system for Salmonella enterica. Gene 377, 6-11. doi: 10.1016/i.gene.2006.02.013

Lee, S. Y., Choi, J. H., and Xu, Z. (2003). Microbial cell-surface display. Trends Biotechnol. 21, 45-52. doi: 10.1016/S0167-7799(02)00006-9

Letek, M., Valbuena, N., Ramos, A., Ordonez, E., Gil, J. A., and Mateos, L. M. (2006). Characterization and use of catabolite-repressed promoters from gluconate genes in Corynebacterium glutamicum. J. Bacteriol. 188, 409-423. doi: $10.1128 / J B .188 .2 .409-423.2006$

Li, M. (2000). Applications of display technology in protein analysis. Nat. Biotechnol. 18, 1251-1256. doi: 10.1038/82355

Liu, L., Yang, H., Shin, H. D., Li, J., Du, G., and Chen, J. (2013). Recent advances in recombinant protein expression by Corynebacterium, Brevibacterium, and Streptomyces: from transcription and translation regulation to secretion pathway selection. Appl. Microbiol. Biotechnol. 97, 9597-9608. doi: 10.1007/s00253-013-5250-x

Liu, Q., Ouyang, S. P., Kim, J., and Chen, G. Q. (2007). The impact of PHB accumulation on L-glutamate production by recombinant Corynebacterium glutamicum. J. Biotechnol. 132, 273-279. doi: 10.1016/j.jbiotec.2007.03.014

Liu, Q., Zhang, J., Wei, X. X., Ouyang, S. P., Wu, Q., and Chen, G. Q. (2008). Microbial production of $\mathrm{L}$-glutamate and $\mathrm{L}$-glutamine by recombinant Corynebacterium glutamicum harboring Vitreoscilla hemoglobin gene $\mathrm{vgb}$. Appl. Microbiol. Biotechnol. 77, 1297-1304. doi: 10.1007/s00253-007-1254-8

Makoto Tsuchiya, Y. M. (1988). Genetic control systems of Escherichia coli can confer inducible expression of cloned genes in coryneform bacteria. Nat. Biotechnol. 1, 428-430. doi: 10.1038/nbt0488-428
Makrides, S. C. (1996). Strategies for achieving high-level expression of genes in Escherichia coli. Microbiol. Rev. 60, 512-538.

Martineau, P., Charbit, A., Leclerc, C., Werts, C., O'callaghan, D., and Hofnung, M. (1991). A genetic system to elicit and monitor antipeptide antibodies without peptide synthesis. Biotechnology 9, 170-172.

Matsuda, Y., Itaya, H., Kitahara, Y., Theresia, N. M., Kutukova, E. A., Yomantas, Y. A., et al. (2014). Double mutation of cell wall proteins CspB and PBP1a increases secretion of the antibody Fab fragment from Corynebacterium glutamicum. Microb. Cell Fact. 13:56. doi: 10.1186/1475-2859-13-56

Matsumoto, K., Kitagawa, K., Jo, S. J., Song, Y., and Taguchi, S. (2011). Production of poly(3-hydroxybutyrate-co-3-hydroxyvalerate) in recombinant Corynebacterium glutamicum using propionate as a precursor. J. Biotechnol. 152, 144-146. doi: 10.1016/j.jbiotec.2010.07.031

Maurer, J., Jose, J., and Meyer, T. F. (1997). Autodisplay: one-component system for efficient surface display and release of soluble recombinant proteins from Escherichia coli. J. Bacteriol. 179, 794-804. doi: 10.1128/jb.179.3.794-804.1997

Nakata, K., Inui, M., Balázs Kós, P., Vertes, A. A., and Yukawa, H. (2003). Vectors for genetic engineering of Corynebacteria. Am. Chem. Soc. 862, 175-191. doi: 10.1021/bk-2003-0862.ch011

Nakayama, K., Kitada, S., and Kinoshita, S. (1961). The control mechanism on lysine accumulation by homoserine and threonine. J. Gen. Appl. Microbiol. 7, 145-154 doi: 10.2323/jgam.7.145

Nguyen, H. D., Phan, T. T., and Schumann, W. (2007). Expression vectors for the rapid purification of recombinant proteins in Bacillus subtilis. Curr. Microbiol. 55, 89-93. doi: 10.1007/s00284-006-0419-5

Oh, Y. H., Choi, J. W., Kim, E. Y., Song, B. K., Jeong, K. J., Park, K., et al. (2015). Construction of synthetic promoter-based expression cassettes for the production of cadaverine in recombinant Corynebacterium glutamicum. Appl. Biochem. Biotechnol. 176, 2065-2075. doi: 10.1007/s12010-015-1701-4

Okibe, N., Suzuki, N., Inui, M., and Yukawa, H. (2010). Isolation, evaluation and use of two strong, carbon source-inducible promoters from Corynebacterium glutamicum. Lett. Appl. Microbiol. 50, 173-180. doi: 10.1111/j.1472-765X.2009.02776.x

Okino, S., Suda, M., Fujikura, K., Inui, M., and Yukawa, H. (2008). Production of D-lactic acid by Corynebacterium glutamicum under oxygen deprivation. Appl. Microbiol. Biotechnol. 78, 449-454. doi: 10.1007/s00253-007-1336-7

Otten, A., Brocker, M., and Bott, M. (2015). Metabolic engineering of Corynebacterium glutamicum for the production of itaconate. Metab. Eng. 30, 156-165. doi: 10.1016/j.ymben.2015.06.003

Park, J. U., Jo, J. H., Kim, Y. J., Chung, S. S., Lee, J. H., and Lee, H. H. (2008). Construction of heat-inducible expression vector of Corynebacterium glutamicum and C. ammoniagenes: fusion of lambda operator with promoters isolated from C. ammoniagenes. J. Microbiol. Biotechnol. 18, 639-647.

Park, S. D., Lee, S. N., Park, I. H., Choi, J. S., Jeong, W. K., Kim, Y., et al. (2004). Isolation and characterization of transcriptional elements from Corynebacterium glutamicum. J. Microbiol. Biotechnol. 14, 789-795.

Peters-Wendisch, P. G., Schiel, B., Wendisch, V. F., Katsoulidis, E., Mockel, B., Sahm, H., et al. (2001). Pyruvate carboxylase is a major bottleneck for glutamate and lysine production by Corynebacterium glutamicum. J. Mol. Microbiol. Biotechnol. 3, 295-300.

Peyret, J. L., Bayan, N., Joliff, G., Gulik-Krzywicki, T., Mathieu, L., Schechter, E., et al. (1993). Characterization of the cspB gene encoding PS2, an ordered surface-layer protein in Corynebacterium glutamicum. Mol. Microbiol. 9, 97-109. doi: 10.1111/j.1365-2958.1993.tb01672.x

Rytter, J. V., Helmark, S., Chen, J., Lezyk, M. J., Solem, C., and Jensen, P. R. (2014). Synthetic promoter libraries for Corynebacterium glutamicum. Appl. Microbiol. Biotechnol. 98, 2617-2623. doi: 10.1007/s00253-013-5481-x

Sanchez-Garcia, L., Martin, L., Mangues, R., Ferrer-Miralles, N., Vazquez, E., and Villaverde, A. (2016). Recombinant pharmaceuticals from microbial cells: a 2015 update. Microb. Cell Fact. 15:33. doi: 10.1186/s12934-016-0437-3

Schallenberger, M. A., Niessen, S., Shao, C., Fowler, B. J., and Romesberg, F. E. (2012). Type I signal peptidase and protein secretion in Staphylococcus aureus. J. Bacteriol. 194, 2677-2686. doi: 10.1128/JB.00064-12

Scheele, S., Oertel, D., Bongaerts, J., Evers, S., Hellmuth, H., Maurer, K. H., et al. (2013). Secretory production of an FAD cofactor-containing cytosolic enzyme (sorbitol-xylitol oxidase from Streptomyces coelicolor) using the twinarginine translocation (Tat) pathway of Corynebacterium glutamicum. Microb. Biotechnol. 6, 202-206. doi: 10.1111/1751-7915.12005 
Schneider, J., Eberhardt, D., and Wendisch, V. F. (2012). Improving putrescine production by Corynebacterium glutamicum by fine-tuning ornithine transcarbamoylase activity using a plasmid addiction system. Appl. Microbiol. Biotechnol. 95, 169-178. doi: 10.1007/s00253-012-3956-9

Scotti, P. A., Valent, Q. A., Manting, E. H., Urbanus, M. L., Driessen, A. J., Oudega, B., et al. (1999). SecA is not required for signal recognition particle-mediated targeting and initial membrane insertion of a nascent inner membrane protein. J. Biol. Chem. 274, 29883-29888. doi: 10.1074/jbc.274.42.29883

Shin, K. C., Sim, D. H., Seo, M. J., and Oh, D. K. (2016). Increased production of food-grade d-tagatose from d-Galactose by permeabilized and immobilized cells of Corynebacterium glutamicum, a GRAS host, expressing d-galactose isomerase from Geobacillus thermodenitrificans. J. Agric. Food Chem. 64, 8146-8153. doi: 10.1021/acs.jafc.6b03588

Singh, R., Kraft, C., Jaiswal, R., Sejwal, K., Kasaragod, V. B., Kuper, J., et al. (2014). Cryo-electron microscopic structure of SecA protein bound to the $70 \mathrm{~S}$ ribosome. J. Biol. Chem. 289, 7190-7199. doi: 10.1074/jbc.M113.506634

Smith, G. P. (1985). Filamentous fusion phage: novel expression vectors that display cloned antigens on the virion surface. Science 228, 1315-1317. doi: $10.1126 /$ science. 4001944

Smith, M. D., Flickinger, J. L., Lineberger, D. W., and Schmidt, B. (1986). Protoplast transformation in coryneform bacteria and introduction of an alpha-amylase gene from Bacillus amyloliquefaciens into Brevibacterium lactofermentum. Appl. Environ. Microbiol. 51, 634-639.

Song, Y., Matsumoto, K., Tanaka, T., Kondo, A., and Taguchi, S. (2013). Singlestep production of polyhydroxybutyrate from starch by using alpha-amylase cell-surface displaying system of Corynebacterium glutamicum. J. Biosci. Bioeng. 115, 12-14. doi: 10.1016/j.jbiosc.2012.08.004

Srivastava, P., and Deb, J. K. (2002). Construction of fusion vectors of corynebacteria: expression of glutathione-S-transferase fusion protein in Corynebacterium acetoacidophilum ATCC 21476. FEMS Microbiol. Lett. 212, 209-216. doi: 10.1111/j.1574-6968.2002.tb11268.x

Srivastava, P., and Deb, J. K. (2005). Gene expression systems in corynebacteria. Protein Expr. Purif. 40, 221-229. doi: 10.1016/j.pep.2004.06.017

Suzuki, N., Watanabe, K., Okibe, N., Tsuchida, Y., Inui, M., and Yukawa, H. (2009). Identification of new secreted proteins and secretion of heterologous amylase by C. glutamicum. Appl. Microbiol. Biotechnol. 82, 491-500. doi: 10.1007/s00253-008-1786-6

Tateno, T., Fukuda, H., and Kondo, A. (2007). Production of L-Lysine from starch by Corynebacterium glutamicum displaying alpha-amylase on its cell surface. Appl. Microbiol. Biotechnol. 74, 1213-1220. doi: 10.1007/s00253-00 6-0766-y

Tateno, T., Okada, Y., Tsuchidate, T., Tanaka, T., Fukuda, H., and Kondo, A. (2009). Direct production of cadaverine from soluble starch using Corynebacterium glutamicum coexpressing alpha-amylase and lysine decarboxylase. Appl. Microbiol. Biotechnol. 82, 115-121. doi: 10.1007/s00253-008-1751-4

Teramoto, H., Watanabe, K., Suzuki, N., Inui, M., and Yukawa, H. (2011). High yield secretion of heterologous proteins in Corynebacterium glutamicum using its own Tat-type signal sequence. Appl. Microbiol. Biotechnol. 91, 677-687. doi: 10.1007/s00253-011-3281-8

Tsuchidate, T., Tateno, T., Okai, N., Tanaka, T., Ogino, C., and Kondo, A. (2011). Glutamate production from beta-glucan using endoglucanase-secreting Corynebacterium glutamicum. Appl. Microbiol. Biotechnol. 90, 895-901. doi: $10.1007 /$ s00253-011-3116-7

Tsuge, Y., Tateno, T., Sasaki, K., Hasunuma, T., Tanaka, T., and Kondo, A. (2013). Direct production of organic acids from starch by cell surface-engineered
Corynebacterium glutamicum in anaerobic conditions. AMB Express 3:72. doi: 10.1186/2191-0855-3-72

Tuteja, R. (2005). Type I signal peptidase: an overview. Arch. Biochem. Biophys. 441, 107-111. doi: 10.1016/j.abb.2005.07.013

van Ooyen, J., Noack, S., Bott, M., Reth, A., and Eggeling, L. (2012). Improved L-lysine production with Corynebacterium glutamicum and systemic insight into citrate synthase flux and activity. Biotechnol. Bioeng. 109, 2070-2081. doi: 10.1002/bit.24486

van Wely, K. H., Swaving, J., Freudl, R., and Driessen, A. J. (2001). Translocation of proteins across the cell envelope of Gram-positive bacteria. FEMS Microbiol. Rev. 25, 437-454. doi: 10.1111/j.1574-6976.2001.tb00586.x

von Heijne, G. (1985). Signal sequences. The limits of variation. J. Mol. Biol. 184, 99-105. doi: 10.1016/0022-2836(85)90046-4

Xu, D., Tan, Y., Shi, F., and Wang, X. (2010). An improved shuttle vector constructed for metabolic engineering research in Corynebacterium glutamicum. Plasmid 64, 85-91. doi: 10.1016/j.plasmid.2010.05.004

Yang, J., Li, J., Men, Y., Zhu, Y., Zhang, Y., Sun, Y., et al. (2015). Biosynthesis of l-Sorbose and l-Psicose based on c-C bond formation catalyzed by aldolases in an engineered Corynebacterium glutamicum strain. Appl. Environ. Microbiol. 81, 4284-4294. doi: 10.1128/AEM.00208-15

Yao, W., Chu, C., Deng, X., Zhang, Y., Liu, M., Zheng, P., et al. (2009). Display of alpha-amylase on the surface of Corynebacterium glutamicum cells by using $\mathrm{NCgl1221}$ as the anchoring protein, and production of glutamate from starch. Arch. Microbiol. 191, 751-759. doi: 10.1007/s00203-009-0506-7

Yim, S. S., An, S. J., Choi, J. W., Ryu, A. J., and Jeong, K. J. (2014). High-level secretory production of recombinant single-chain variable fragment (scFv) in Corynebacterium glutamicum. Appl. Microbiol. Biotechnol. 98, 273-284. doi: 10.1007/s00253-013-5315-x

Yim, S. S., An, S. J., Kang, M., Lee, J., and Jeong, K. J. (2013). Isolation of fully synthetic promoters for high-level gene expression in Corynebacterium glutamicum. Biotechnol. Bioeng. 110, 2959-2969. doi: 10.1002/bit.24954

Yim, S. S., Choi, J. W., Lee, R. J., Lee, Y. J., Lee, S. H., Kim, S. Y., et al. (2016) Development of a new platform for secretory production of recombinant proteins in Corynebacterium glutamicum. Biotechnol. Bioeng. 113, 163-172. doi: 10.1002/bit.25692

Zahoor, A., Otten, A., and Wendisch, V. F. (2014). Metabolic engineering of Corynebacterium glutamicum for glycolate production. J. Biotechnol. 192(Pt.B), 366-375. doi: 10.1016/j.jbiotec.2013.12.020

Zhang, B., Yu, M., Zhou, Y., and Ye, B. C. (2018). Improvement of L-ornithine production by attenuation of argF in engineered Corynebacterium glutamicum S9114. AMB Express 8:26. doi: 10.1186/s13568-018-0557-8

Zhang, Y., Shang, X., Lai, S., Zhang, G., Liang, Y., and Wen, T. (2012). Development and application of an arabinose-inducible expression system by facilitating inducer uptake in Corynebacterium glutamicum. Appl. Environ. Microbiol. 78, 5831-5838. doi: 10.1128/AEM.01147-12

Conflict of Interest Statement: The authors declare that the research was conducted in the absence of any commercial or financial relationships that could be construed as a potential conflict of interest.

Copyright (C) 2018 Lee and Kim. This is an open-access article distributed under the terms of the Creative Commons Attribution License (CC BY). The use, distribution or reproduction in other forums is permitted, provided the original author(s) and the copyright owner(s) are credited and that the original publication in this journal is cited, in accordance with accepted academic practice. No use, distribution or reproduction is permitted which does not comply with these terms. 